\title{
Fragmented and Oblique Autobiographies and Memoirs
}

The Case of Madame de Genlis

Autobiographies et mémoires fragmentés et obliques : l'exemple de Mme de Genlis

\section{Marie-Emmanuelle Plagnol}

Translator. Colin Keaveney

\section{(2) OpenEdition}

\section{Journals}

Electronic version

URL: http://journals.openedition.org/aes/782

DOI: $10.4000 /$ aes. 782

ISSN: 2258-093X

Publisher

Laboratoire LISAA

\section{Electronic reference}

Marie-Emmanuelle Plagnol, «Fragmented and Oblique Autobiographies and Memoirs », Arts et Savoirs [Online], 6 | 2016, Online since 07 July 2016, connection on 20 April 2019. URL : http://

journals.openedition.org/aes/782; DOI : 10.4000/aes.782

This text was automatically generated on 20 April 2019.

Centre de recherche LISAA (Littératures SAvoirs et Arts) 


\title{
Fragmented and Oblique Autobiographies and Memoirs
}

\author{
The Case of Madame de Genlis \\ Autobiographies et mémoires fragmentés et obliques : l'exemple de Mme de \\ Genlis
}

\section{Marie-Emmanuelle Plagnol}

Translation : Colin Keaveney

1 The context in which fragmented and oblique autobiographies and memoirs were written at the turn of the Eighteenth into the Nineteenth Century is revealing of the status of women writers. One of the ways women could gain entry into the Republic of Letters was by means of the memoir. There was a simple reason for this, one which is true of educational texts in general: the progressive emergence and legitimization of women took place in the minor genres, which touched on the roles and qualities usually assigned to them. Thus, while they were not acknowledged as historiographers - i.e. writing about history in an official capacity - publishers were wont to turn to women to reflect on a world turned upside down by regime change, or engulfed by the Revolution. The Restoration vogue for memoirs, particularly by women, either published singly or as part of collections, is well known; it reveals the strength of publisher and reader demand, which emerged from the expectations of an audience encouraged to engage with these personal accounts. This responsiveness is in play from the start in the choice of a title. Thus, Madame de Caylus' work, as well as others more recently published, prompted the following retort from Madame de Boigne: "Memories: Madame de Caylus has made this title difficult to bear and recent publications have done much to sully it." ${ }^{1}$ The same intertextuality, albeit with opposite effects, lay behind Madame de Genlis' choice of title for one of her numerous autobiographies; these two contrasting examples of how such works were received (or how they were reportedly received) are revealing of the ethical debate that surrounded female memoirs:

In French, we already had two works bearing the title of Memories. The first was the (in every respect) charming volume authored by Madame de Caylus. Everything 
about this work is perfect - the feelings, the narrative style, its grace. [...] As for the Memories of Madame Necker, readers judged it in a manner that her supporters may have found severe, but which is merely fair. I even venture to say that, without the reputation this famous woman deservedly enjoys, without the unblemished character of her conduct and life, this pitiful work would have seriously tarnished her image in the minds of all persons of feeling. ${ }^{2}$

Since these were women writing their memoirs, the fundamental ambiguity lay in the particular value given to their views, which stemmed from their ability to conjure up former splendors, in accordance with the role that parallel histories allowed them: they were prized in their capacity as hosts in the world of intellectual salon culture, as guardians of old Regime ${ }^{3}$ sociability, and less as witnesses (not to mention historical "actors") of a period they had lived through but which, out of dutiful discretion, especially in the case of aristocrats, they refused to depict and analyze "historically". This huge body of texts and the problems it raises has excited a good deal of interest among researchers and the scholarly literature is abundant ${ }^{4}$. This is why I shall concentrate on Madame de Genlis, whose varied contributions to these interrelated genres seem to me to be exemplary for several reasons.

Despite what she says, and particularly because of what she remains silent about, spins, or factually modifies, Madame de Genlis was a political player. Hers is not simply an "I saw" type of account; there is plenty of "I did" in her writings, although the revelations in this regard are full of gaps. Moreover, her longevity and productivity gave rise to parallel bodies of work, literary and memoir, which occasionally intersect and tend to create a fragmentary and oblique picture of her life, hence my title. Born in 1746 and deceased in 1830, she was appointed as "governess" to the children of the House of Orleans. During this period of about eight years (1782-1790), which she conceived of in terms of a mission, she wrote a number of pedagogical works idealizing her methods, such as Adèle et Théodore (a work which would not receive the Montyon prize, given instead to Madame d'Epinay's Conversations d'Émilie) and Les Veillées du château. Emigration did not put paid to her productivity and, once back in France, she pursued a highly industrious career wielding moral conservatism and didacticism in all literary genres she turned to her ends. Among this highly multifarious production, the texts which contain self-depictions including those where these depictions are fleeting and would subsequently be reprised in other rather more obviously autobiographical texts - are numerous and varied. Among the non-autobiographical works in which Madame de Genlis portrays herself "obliquely", in chronological order, there are the educational works of the Pavilion of Bellechasse period (in Paris, where she used to live with her pupils):

- 1779-1780 : Théâtre à l'usage des jeunes personnes, 4 vols., Paris, M. Lambert et F.-J. Baudouin.

- 1782 : Adèle et Théodore ou Lettres sur l'éducation contenant tous les principes relatifs aux trois plans d'éducation des princes, des jeunes personnes et des hommes, 3 vol., Paris, M. Lambert et F.-J. Baudouin.

- 1782: Les Veillées du château ou Cours de morale à l'usage des enfants par l'auteur d'Adèle et Théodore, 4 vols., Paris, M. Lambert et F.-J. Baudouin.

- 1785 : Théâtre à l'usage des jeunes personnes, 7 vols., Paris, M. Lambert.

- The works of the Revolutionary period, which stemmed directly from a need to make political justifications for the Orleanist movement of which she was a strong supporter, as well as her positioning taking with regard to the political maneuvers of her pupil, Louis Philippe, include: 
- 1791 : Leçons d'une gouvernante à ses élèves ou fragments d'un journal qui a été fait pour l'éducation des enfants de monsieur d'Orléans par madame de Sillery-Brulart (sic), 2 vols., Paris, Onfroy.

- 1796 : Précis sur la conduite de Mme de Genlis, depuis la Révolution, suivi d'une lettre à M. de Chartres et de réflexions sur la critique, Hamburg, B.G. Hoffman. ${ }^{5}$ content, l'Epitre à l'asile que j'aurai, suivie de deux fables, du Chant d'une jeune sauvage, de l'Epître à Henriette Sercey et des réflexions d'un ami des talents et des arts, Hamburg, P.F. Fauche.

5 Finally, the autobiographical period ${ }^{6}$ stretches from 1804 to 1828 , quite openly articulated around the hefty Mémoires inédits of 1825, and includes:

- 1804 : Les souvenirs de Félicie L**, Paris, Maradan.

- 1807 : Suite des souvenirs de Félicie L**, Paris, Maradan.

- 1825 : Mémoires inédits de madame la comtesse de Genlis sur le dix-huitième siècle et la Révolution française depuis 1756 jusqu'à nos jours, Paris, Ladvocat, 10 vols.

- 1828 : Le Dernier voyage de Nelgis ou Mémoires d'un vieillard, 2 vols., Paris, Roux.

To these already highly diverse works - in terms of their form, intended audience and putative subject - should be added an abundant correspondence, unpublished in Madame de Genlis' lifetime, which already offers insights into to what we now call "private life" in particular the love letters, and those written to offspring offering motherly advice. In the order in which they appeared:

- Lettres inédites de Mme de Genlis à son fils adoptif Casimir Becker (1801-1830), publiées avec une introduction et des notes, d'après des documents nouveaux, Ed. Henri Lapauze, Paris, Plon-Nourrit et Cie, 1902.

- L'Idylle d'un " gouverneur ». La comtesse de Genlis et le duc de Chartres [correspondance], Éd. Gaston Maugras, Paris, Plon-Nourrit et Cie., 1904.

- Madame de Genlis et la grande duchesse Élisa (1811-1813). Lettres inédites suivies de l'ouvrage sur les « Mœurs de l'ancienne cour », Ed. Paul Marmottan, Paris, E. Paul, 1912.

- Le Dernier amoureux de madame de Genlis, Correspondance inédite de la Comtesse de Genlis et du comte Anatole de Montesquiou, Ed. André Castelot, Paris, Grasset, 1954.

- The Unpublished Correspondence of Madame de Genlis and Margaret Chinnery and Related Document in the Chinnery Family Papers, Ed. Denise Yim, Oxford, Voltaire Foundation, Studies on Voltaire and the Eighteenth Century, 2, 2003.

7 This excessively long presentation of the context in which Madame de Genlis was writing is nevertheless necessary in order to differentiate her memoir writing from her oblique autobiographies, both of which took divergent paths to arrive at fragmented and reconstructed images of the private self.

\section{Madame de Genlis' Conception and Practice of the Memoir $^{7}$}

We shall take as our focus the Mémoires of 1825, which, at least in their title and organization, give every appearance of belonging to this genre. As with Baroness $d$ 'Oberkirch, Madame de Boigne and Madame de Chastenay, her memoir does not emerge ex nihilo, but was inspired by previous texts - both literary or non-literary. Generally composed some time after the events it reports - the amount of time varies - the memoir as a genre often drew on correspondence and diaries, two analytical forms of writing 
about the self used by young women and girls. Madame de Genlis was no exception. For long periods of her life, she kept diaries or kept various notes which could serve as memory aids when it came to finally writing her books. The work methods she mentions are closely related to the moral stance and the supposed genesis of the Mémoires. Following a method mentioned in most of her paratexts, Madame de Genlis claims to have read the memoirs of all her contemporaries up until 1812 and to have cross-referenced them with a "personal diary" 8 updated each evening over the previous 15 years, a period she had spent in "the very best circles". Her approach to history was complex and original: it was not limited to the genre of memoir since Madame de Genlis wrote several historical novels on, among other topics, the reigns of Louis XIII and Louis XIV, and she also openly practiced parallel history as evidenced by the following title: Les Chevaliers $d u$ cygne, ou la cour de Charlemagne, contes pour servir de suite aux "Veillées du château » et dont tous les traits qui peuvent faire allusion à la Révolution française sont tirés de l'histoire ${ }^{10}([. .$.$] in$ which Every Feature that can be read as an Allusion to the French Revolution is drawn from History). On the memoir front, she combines an engagement in public political debate, and even political activism, with a discretion pact. Nevertheless, even if her prefaces or opening pages of her autobiographical accounts generally rehash a variation on the theme of retirement, Madame de Genlis makes use of her status to justify publishing during her lifetime: "I felt that it would be repeated that one should not draw attention to oneself, that women should be especially careful to avoid the public glare, etc. etc." ${ }^{11}$. It is precisely because she is a woman of letters, a title she lays claim to in 1825 , that publishing holds no fears for her:

An author who has printed a large number of volumes and, for 50 years has constantly attacked misguided doctrines in other word the philosophists, is only too accustomed to being the center of attention; I am also utterly unaffected by the injustices, satirical writings, broadsides and the fear of being the center of attention. ${ }^{12}$

9 The preface to tome I and the first four pages of the text itself make clear her position, this time from a moral standpoint.

Every author is obliged to stand by their work - that goes without saying -,since it is also understood that it is cowardly to publish criticisms anonymously. [...] To leave memoirs behind that one would have been afraid to publish during one's lifetime is to render their veracity suspect..$^{13}$

She then goes on to explain her motives. She intends to bear witness to history ("the times I lived through, the things which happened before my very eyes ${ }^{14 ")}$ to literary affairs ("Firstly, I knew almost all the famous writers in this century and in my youth I was acquainted with those of the previous century"15), to a bygone and forgotten age ("I could paint a faithful portrait of an extinct or fragmented group of people, and of a century that is not only past, but erased from the memory of those who are alive today"16 ). The apparent contradiction between the traditional self-effacement expected of women, her own character, and this acceptance, not to say downright cultivation, of publicity, is not concealed, as is clear when she gives the following moral justification, which is supported by her actions defined in moral and religious terms, particularly her struggle against the philosophes:

At any rate, I considered that my literary life was not devoid of interest, and that it would be intriguing to see how someone so attached to solitude, the quiet life and the arts, and someone so gentle, timid and reserved of character could have resolved to speak so loudly, to play such a public role, and to engage in endless battles. ${ }^{17}$ 
11 Her desire to tell the truth in the face of her enemies ("to clear the record" 18 ), her age ("In one's seventies, when one has suffered so much, when one is worn down by a long effort" ${ }^{19}$ ), the dialogue with God, which should be read as a riposte to the opening of Rousseau's Confessions ${ }^{20}$, as well as the factual simplicity of the book's first line ("I was born on the 25 January 1746 in a small corner of Burgundy"21) bolsters this explanation. Her conception of history is indebted to Bossuet: religion should be the only guide in writing history, as is clearly evident in chapter 15 of tome VIII of the Mémoires, as in her constant criticism of secular histories. This conviction allows her to put forward a strict moral rule: be content to tell things as they were, to point out errors without accusing anyone, but judge rigorously works that are contrary to morality. Truth and criticism must be guided by morality and religion, not resentment. She claims thus to have even praised her enemies in good faith as long as they were "irreproachable in this respect ${ }^{22}$ "...

Out of the many available, three examples, each of a different type, dealing with criticism, the private realm, and political activity, show how these declarations have real consequences in the 1825 edition of the Mémoires.

Regarding the contemporary figures she criticizes, we shall only deal with Madame de Montesson, while setting aside what she has to say about the Queen, Marie-Antoinette, or the Princess de Lamballe. Madame de Genlis had a strained relationship of rivalry with the woman she nicknamed "tantâtre" (the evil step-aunt), whose literary ambitions she ridiculed and talents as an actress she criticized against the prevailing view held by almost everyone in polite society. The topic is so sensitive that Madame de Genlis takes it on immediately after setting out her good intentions. She stresses that she has not told all ("I'm far from having gone into all the details") and foregrounds her closest family members ("it was impossible for me to sacrifice [the reputation] of my mother and brother"). Her relation with her aunt is depicted as being exemplary; she is only telling the truth: "proving based on facts that Madame de Montesson has never been my benefactor, that she has never once in her life done me the slightest favor, and that she has harmed me a good deal". At the same time, Madame de Genlis defends her against a false accusation ("I even vindicate her against a particularly libelous accusation believed by many") and, moreover, praises her in an original way: "I recount a charming aspect of her character that no one else knows about"23.

One suspects that, conceived and executed in this spirit, the Mémoires excluded everything that could be considered personal and that anything private was out of bounds. They make no mention, of course, of her affair with the Duke d'Orléans ${ }^{24}$, or of an adulterous pregnancy disguised by a trip to Forges, and they give a morally acceptable explanation of her adoption of the young English orphans; the same goes for her estrangement from the Duchesse of Orléans ${ }^{25}$. This disparity between autobiography and biography is even more striking given the fact that contemporary broadsides never spared the governess-mistress and that these different events (affair, suspicious adoptions, rivalry, estrangement ending in de facto separation from the Count de Genlis) were widely known to a public imbued with misogyny and hostility to Madame de Genlis' moralizing and anti-Enlightenment stance ${ }^{26}$.

Just like the private realm, the role of the political is denied or, at least, played down. The political campaign Madame de Genlis had her pupil lead and the writings of that period (in particular the Discours) confirm her engagement in the cause of change. The facts and the Lettres d'une gouvernante à ses élèves ${ }^{27}$ echo her commitment and that of her pupil to 
the cause of 1789. Under the Restoration, she had to deny the role of political motives in favor of those of morality and religion, the pillars of the regime: Christian charity (not beneficence...) became the sole explanation for her militancy against hunting, primogeniture and prisons (the Bastille or the iron cage on the Mont Saint-Michel). The Lettre de Silk ${ }^{28}$ goes even further in confirming her break with the initial political project constructed around Louis-Philippe...

\section{Masks and Oblique Self-Portraits}

These are precisely the difficulties that gave rise to workaround strategies and hybrid essays like theatrical or narrative self-fiction, or occasionally to even rarer genres combinations. Certain articles in the Dictionnaire critique et raisonné des étiquettes.... ${ }^{29}$ are revealing in this respect. The text is itself problematic and lends itself to number of different interpretations and uses ${ }^{30}$, even more so because it was reprinted at the end of Tome X of the Mémoires ${ }^{31}(1825)$. To take just one example: the article "Governess of Children of Princes" commences with a definition and concludes with a thinly disguised self-portrait, which refers of course to Madame de Genlis, but also to all the texts, fictional or not, depicting her:

It is clear that only once has a single person, charged with the education of the princes of the blood, carried out all the duties of a tutor, given five to six hours of lessons herself, supervised the other lessons and, in addition, selected all the readings. This person accomplished something really extraordinary because there was no example to follow, but she never overdid anything; this is the duty of any governess of princes or private individuals. ${ }^{32}$

These idealized figures of "governess", mother and educator are to be found throughout the theatrical works where they must have stood out very sharply for the audiences of these plays, which physically depicted Madame de Genlis surrounded by her children and her pupils. The oblique portrait could take two distinct forms: one where there is a double in the text (as in La Bonne mère ${ }^{33}$, a comedy typical of this approach which we also find in the pedagogical novels of Madame de Genlis) or where there is a transposition whose rules are explained in the peritexts. Thus, the biblical play Ruth et Noémie in tome I of the religious plays in the 1785 edition includes, between the list of the dramatis personae and the notice which deals mainly with sources and their treatment by Madame de Genlis, a preface to Pamela, her adopted daughter, in which its "applications" are explained. Madame de Genlis had read the story of Ruth to Pamela, who was taken by it and asked her adoptive mother to write a play on the topic, a play which is not only dedicated, but addressed to her (in the full meaning of that word). The reader is thus tempted to imagine all sorts of parallels:

No one is better placed than you to judge if I have faithfully represented the gratitude and attachment that the tender care of an adoptive mother should inspire. If you find that Ruth, when she speaks to Noémie, expresses what you feel, I will be satisfied with what I have written.

Similarly, several memories that would later be published in the Mémoires had already been depicted in the theater. A case in point is the metamorphosis of the little girl (the future Madame de Genlis) into a Parisian in order to go to a ball ${ }^{34}$ : dressed up as the type of shepherdess one saw in the city, decked out with an enormous hairdo, a wig, squeezed into a "corset", with a hoop and a garlanded dress, she was unable to dance and was utterly bored at a ball she had so been looking forward to. The autobiographical details 
were first given a humorous, yet instructive, treatment by the heroine of La Colombe, one of the plays included in Théâtre à l'usage des jeunes personnes ${ }^{35}$. Similarly, Madame de Genlis also uses on several occasions her participation in Rosière de Salency ceremonies. To recall, in 1766, Le Pelletier de Morfontaine, intendant in Soissons, attended the Salency ceremony and the inhabitants requested via the bailiff that he crown the rosière (rose queen). He added forty écus to the prize after his death to the dowry of the rose queen for one year after their crowning. Thus began a long line of personalities who would lend their moral, political and artistic support to the event. Accompanied by the Marquise de Genlis, the Count and Countess de Genlis, Le Pelletier de Morfontaine gave a huge ball in a refitted barn, where the men wrote couplets (some of which were published, notably in Le Mercure). Madame de Genlis handed out presents, played the harp and sang. This phase of moral and political utopianism in the Feast of the Rosière is recounted in the Mémoires ${ }^{36}$, as is Madame de Genlis' support for the townspeople of Salency when they defended their right to name the rose queen. In addition to the Plaidoyer en faveur de la rosière, pour les syndic (sic) et habitants du village de Salency, contre le Sieur Danré, seigneur dudit Salency ${ }^{37}$ by Maitre Target, we also find a report to the prior of Salency written by Madame de Genlis, which is also mentioned in the Mémoires. ${ }^{38}$ This first visit to Salency inspired the play La Rosière de Salency published in tome V of the Théatre d'éducation, aimed "at the children of merchants and artisans", published in 1779. The comedy, conceived as a dramatized account as given by a female merchant form Noyon, was preceded by a notice in which Madame de Genlis mentions Target while omitting any reference to his part in the polemic ${ }^{39}$ and avoiding any mention of herself. On the other hand, in L'Aveugle de Spa ${ }^{40}$ , which is part of the literary vein dedicated to virtuous anecdotes in which the second half of the Eighteenth Century abounds, she makes clear reference to herself in the opening notice to the reader:

The subject of this play is not an invention; three years ago in Spa, we saw this virtuous woman, Madame Aglebert, and we got this story from the poor blind woman herself. All the details about Madame Aglebert in this play are strictly true; we have changed nothing, not even her name, those of her children, how many they are and her husband's profession. It is also true that an English lady, who was in Spa at the time, did much to help this respectable family.

These idealized doubles are at the center of Madame de Genlis' pedagogical novels, notably Adèle et Théodore and Les Veillées du château which take place in family and educational settings where the focus is on mothers: Madame d'Almane in the first (even if the character of Mr. d'Almane, in charge of instructing his son, allows for the outlining of certain gendered aspects of childhood education) and Madame de clémire in the second. The reflexivity becomes even more complex: the children read the works of Madame de Genlis, in which the fictional mothers are actually the authors of the books that are later brought by traveling salesmen to the castle; the pedagogical décor of the d'Almane's chateau was inspired by Bellechasse, notably the historical vignettes by the painter Sylvestre-David Myris; and a whole apparatus of footnotes underpins the system of reference, just in case the reader might have had any doubts that the experiment really had taken place... And, finally, an onomastic play on the names of the children tops off the referential framework: Adèle is Adélaïde d'Orléans, who was nicknamed Adèle by Madame de Genlis; César the son of Madame de Clémire is a reference to César Ducrest, Madame de Genlis' nephew, whose sisters in the novel are called Caroline and Pulchérie like the real daughters of Madame de Genlis... 
20 Even if they allowed her to present educational projects founded on real and verifiable experience, this play on names did not permit Madame de Genlis to speak of her own memories. Before the weighty memoir of 1825 , her memories were committed to print in two works, Les souvenirs de Félicie $L^{* * *}$ and la Suite des souvenirs de Félicie $L^{* * *}$, in 1804 and 1807 respectively ${ }^{41}$. The peritexts reveal the poetic, generic and editorial choices of Madame de Genlis. The dedication "For Mr. Ducrest" refers to her brother and justifies the absence of any personal secrets: "You will not find those [memories] in this collection, as they could be of interest only to us and I had no need to write them in order to remember." 42

21 The preface explains her reasons for publishing: it was a matter of gathering memories spread out over thirty volumes of the Bibliothèque des Romans and preventing counterfeit editions. All the while following the lead of Madame de Caylus and Madame Necker, whose book she criticizes even though she herself "received favorable and flattering mention" ${ }^{43}$ in it, Madame de Genlis' intention is to reassert certain truths and she takes the opportunity to set out her principles:

My personal feelings of resentment will never prompt me to be unfair, even in my first reactions [...] I do not wish to take credit for this moderation; mere good taste would have been enough to dictate it. The virtue and exceptional merit of Madame Necker temper any criticism one might have with the respect she deserves. ${ }^{44}$

The extremely loose structure of the text allows for the inclusion of recollections or anecdotes about Lekain, Cardinal Richelieu's testament, Madame de Sainval, among others, including Madame Louise in Saint-Denis; but also for a few witticisms or comments on a range of topics such as questions of style or the theatrical figure of the valet. These Souvenirs even include other texts by Madame de Genlis, which are inserted, a tactic used in the later tomes of the Mémoires (1825), which resemble miscellanea, and in Le Dernier voyage de Nelgis ou Mémoires d'un vieillard (1828). Beyond the so-called memoirs, Les souvenirs de Félicie $L^{* * *}$ includes a short story, Gustave, a Journal du voyage d'Italie satirical in tone, a Dialogue entre un académicien et un jeune voyageur (which is also included in tome IX of the 1825 edition of the Mémoires) a tale built around a character named Théophile ("Yesterday, at supper, I heard a someone tell a fine tale. Here it is" ${ }^{45}$ ) and a variety of texts against such fashions as Anglomania, sentimentality and affectation. The common thrust of the anecdotes, the textual interpolations and the views expounded, suggest that behind Félicie $L^{* * *}$ lurks its author, who furthermore plays around with disguises, a move aimed at readers familiar with her life and work. This is announced from the outset in the Préface, where Madame de Genlis declares she was "encouraged to publish a portion of

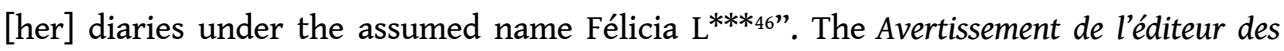
Euvres posthumes de madame de $L^{* * *}$ continues in this playful vein, declaring :

Madame de $\mathrm{L}^{* * *}$ had lived in high society from a very young age: she was spirited, curious, simple and gay. She rarely speaks of herself in her memoirs. However, her character is reflected in her way of seeing, of telling, and of writing. This superficial and frivolous work is meant neither for thinkers nor philosophers, but will perhaps appeal to those who appreciate simplicity and variety. ${ }^{47}$

Félicité, the narrative voice of these Souvenirs, pretends to have no intellectual abilities, but reminds us that she learned to play an instrument at a young age, something she has in common with the future Madame de Genlis. She recounts at length her visit with Voltaire at Ferney ${ }^{48}$, which is identical to the account in the Mémoires ${ }^{49}$ (arriving too early, her towering hairstyle, the impiety of the author, the painter Ott accompanying him, the presence of Marie Françoise Corneille). Similarly, the meeting with Jean-Jacques Rousseau 
and the error of Madame de Genlis (who thought she was talking with Préville disguised as Rousseau, and who thus indulged in all sorts of banter) appear in the Souvenirs ${ }^{50}$ and the Mémoires ${ }^{51}$. A single memory thus supplies several texts. The description of the cemetery in Zug, visited during her period of emigration, is a clear example of this type of multiple use: included in Les Souvenirs de Félicie $L^{* * * 52}$, it is reused in the Mémoires ${ }^{53}$, but also as early as 1805 in Les Monuments religieux, ou Description critique et détaillée des monuments religieux, tableaux et statues [...] églises [...] tombeaux et monastères [...] qui se trouvent maintenant en Europe et dans les autres parties du mond $e^{54}$... This flow from one work to another, whether autobiographical in content or not, was a constant, even a systematic trait, as suggested by the following statement from the Souvenirs: "If ever I become an author, I shall write a work on mythology ${ }^{55}$ "; she actually went on to publish such a work in 1810 with the title Arabesques mythologiques ou Les Attributs de toutes les divinités de la fables en 54 planches gravées d'après les dessins coloriés de Mme de Genlis ${ }^{56}$.

Le Dernier voyage de Nelgis ou Mémoires d'un vieillard ${ }^{57}$, published three years after the Mémoires in 1828, returns to these games of masks with the anagram in its title, of course, but also by its use of an eighty-year-old narrator, the Count de Nelgis, born in Champcéry, who moved to Cosnes at 18 months and Saint-Aubin at four; a traveler, a courtier, an emigrant...Several identity markers are deployed to create a slight distancing of Nelgis from Genlis, between this work and her Mémoires, while encouraging the reader to still identify the two together. This is also the function of the engraving preceding the title page which portrays the chateau of Saint-Aubin, of the dedicatory epistle addressed to the Marquis d'Aligre and, more generally, of the important episodes of his travels, which are just so many memories and occasions to make moral points. ${ }^{58}$ Indeed, the memories attributed to Nelgis are in fact Madame de Genlis' and had already been recounted - at least in the case of the most striking among them - in the Mémoires, which serves as intertext for this final self-fictionalizing text. A case in point is the scene where the future Madame de Genlis carries out her teaching vocation from up on the terrace of the family chateau:

Between the house and the pond ran a little path covered in rushes and reeds, and it was on this path that a few bargemen's children received the lessons, the young canoness, daughter of the deceased lord of the manor, gave to them from high up on the top of the wall..$^{59}$

Not only was the anecdote known and published but, as she does throughout the Dernier voyage de Nelgis, she includes a note referring to the Mémoires of $1825^{60}$. The notes thus intensify the parallels between Nelgis and Genlis, as in this one inserted on the topic of "the little town of Bourbon-Lancy, [...] located two leagues from Saint-Aubain, and where her father was the local lord":

The author of this work, received as a child, at age six, into the noble chapter of Alin, close to Lyon, as a canoness, bore the name of Countess de Lancy from that moment until her marriage, at which time, aged sixteen-and-a-half, she married the Count Brûlart de Genlis. ${ }^{61}$

Notes are also used to mention Madame de Genlis' projects, like the one which compares Doctor Pinot favorably to Tronchin in the treatment of smallpox: "I have not forgotten this marvelous remedy and I shall talk about it in detail in a new edition of the Veillées de la chaumière ${ }^{62 "}$...

Overall, the ideas professed by Nelgis, in the text and footnotes, on religion, mythology, Protestantism, and the disasters of the Revolution, lend themselves to a convergent 
reading in these years when Madame de Genlis was repeating herself from one text to another. Morality sometimes changes the complexion of the anecdotes and gives to these works differing tones. Thus, Nelgis meets an old beggar who reminds him of the role he played in his family theater production during his youth: he was Pleasure, while Nelgis (in reality the young Félicité) was Love. The private parties organized by the mother of the future Madame de Genlis, the costume of Love worn by the little girl that she is so taken by that she didn't want to take it off are all dealt with at length in the Mémoires ${ }^{63}$, which celebrate aristocratic sociability. Any reader familiar with this text can spot the reference to an authentic memory. Divorced from this context, reduced to the pitiful memory of an old man reduced to begging out of laziness, this encounter functions as a moral commentary on the Marquis d'Aligre's policies with regard to indigence: the events told in chapter $\mathrm{XV}^{64}$, entitled "A Touching Conversation-Encounter", are followed by a chapter entitled "Reflections on Sloth"...

Female memoirs play off the complex status of personal testimony. In theory the products of a private conscience and aimed at the writing of private life, these writings are involved in a double intertextuality: with historians and with their immediate contemporaries with which they have resonance. The multifarious works of Mme de Genlis are a fascinating example of the tensions running between memoirs, remembrances, portraits and anecdotes that are there hidden under the surface of these hybrid texts. Her Mémoires of 1825 are highly instructive, but not as a dependable eyewitness account, as certain biographers of Madame de Genlis inclined to literalism have thought. Less an image of the aristocracy of the Ancien Regime (à la the brothers Goncourt), they are instead the difficult, nay impossible account, of the life of a woman at the end of the Enlightenment, as she was caught up in the upheavals of successive political regimes and irreconcilable positions. Above all, they make up a monumental work toward which converge a number of early texts and fragments of various types, in which the author is not above indulging in self-portraiture by means of oblique, onomastic, narrative and ideological references, conceived of as a treasure hunt for the regular reader, who becomes in the process an interlocutor.

\section{NOTES}

1. Mémoires de la comtesse de Boigne, née d'Osmond, récits d'une tante. Edition presented et annotated by Jean-Claude Berchet, Paris, Mercure de France, 1971, t. I, p. 21.

2. Les souvenirs de Félicie $L^{* * *}$, Paris, Maradan, 1804, Préface, p. 5-6. Note: In the interest of clarity and consistency, we have opted to make our own translations of all quotations.

3. To mention just two books among many: L'Esprit de société : cercles et salons parisiens au XVIIIe siècle [texts selected, introduced, presented and annotated; bibliography and index], Jacqueline Hellegouarc'h, prefaced by Marc Fumaroli, Paris, Garnier, 2000 and Antoine Lilti, Le Monde des salons : sociabilité et mondanité à Paris au XVIII eiècle, Paris, Fayard, 2005.

4. For instance, Henri Rossi, Mémoires aristocratiques féminins: 1789-1848, Paris, H. Champion, 1998; Mémorialistes de l'exil : émigrer, écrire, survivre, François Jacob and Henri Rossi eds., Paris, Budapest, Torino, L'Harmattan, 2003; Repenser la Restauration, Conference Proceedings, Paris, Musée de la 
vie romantique et Châtenay-Malabry, Maison de Chateaubriand, septembre 2003, Jean-Yves Mollier, Martine Reid et Jean-Claude Yon eds., Paris, Nouveau monde, 2005; Le Moi, l'histoire, 1789-1848, texts collected by Damien Zanone in collaboration with Chantal Massol, Grenoble, ELLUG, 2005; Damien Zanone, Écrire son temps, Les Mémoires en France de 1815 à 1848, Lyon, Presses Universitaires de Lyon, 2007.

5. Republished in 1828 under the title Étrennes politiques pour 1828. Lettre au duc d'Orléans par Mme la comtesse de Genlis, son institutrice, ou Profession de foi politique en harmonie avec ses actions depuis plus de trente ans en réponse aux pamphlets passés, présents et futurs, Paris, E. Babeuf.

6. We are purposely overlooking Madame de Genlis' editorial involvement in Mémoires de Mme la Mise de Bonchamps, rédigés par Mme la Ctesse de Genlis, Paris, Baudoin frères, 1823.

7. Some of the passages in this section dealing with Madame de Genlis' 1825 Mémoires are taken from my article "Les Mémoires de Madame de Genlis: apprentissage et reconstruction de l'Histoire", séminaire de l'Institut d'Histoire Moderne et Contemporaine, CNRS, ENS, Histoires d'historiennes, Études réunies et présentées par Nicole Pellegrin, Publication of l'Université de SaintÉtienne, Saint-Étienne, 2006, p. 177-187.

8. A note by Madame de Genlis says that this source text has been lost, which is plausible given the large number of preparatory documents and the political situation. Mémoires inédits de madame la comtesse de Genlis sur le dix-huitième siècle et la Révolution française depuis 1756 jusqu'à nos jours, Paris, Ladvocat, tome I, p. 1 (note 1 p. 1-3).

9. Ibid., p. 3.

10. Paris, Lemierre, 1795. A second edition was published the same year by P.F. Fauche in Hamburg.

11. Mémoires inédits..., op. cit., tome I, p. vii.

12. Ibid., p. vii-viii.

13. Ibid., p. iii.

14. Ibid., p. 1.

15. Ibid., p. 2-3.

16. Ibid., p. 3.

17. Ibid., p. 3-4.

18. Ibid., p. 2.

19. Ibid., p. 4.

20. Ibid., p. 5.

21. Ibid., p. 6.

22. Ibid., p. v.

23. Ibid., p. v-vii.

24. See among others J. Harmand, Madame de Genlis, sa vie intime et politique, 1746-1830, Paris, Perrin, 1912 and G. de Broglie, Madame de Genlis, Paris, Perrin, 1985. J. Harmand (see above) has published various letters intercepted by the "black chamber" (mail censor) between 1771 à 1774 . 25. Her fraught relationship with the Duchess d'Orléans was blamed on maternal jealousy.

26. On this topic, see my article, «Aimer ou haïr Madame de Genlis ", Études sur le XVIII siècle, Portraits de femmes, Roland Mortier et Hervé Hasquin eds., (Groupe d'étude du XVIII ${ }^{\mathrm{e}}$ siècle), Bruxelles, éditions de l'Université de Bruxelles, 2000, p. 89-98.

27. Lettres d'une gouvernante à ses élèves ou fragments d'un journal qui a été fait pour l'éducation de Monsieur d'Orléans par madame de Sillery-Brulart (sic), Paris, Onfroy, 1791.

28. Lettre de Mme de Genlis à M. de Chartres, à Silk, pays de Holstein, 18 février 1796.

29. Dictionnaire critique et raisonné des étiquettes de la Cour, des usages du monde, des amusements, des modes, des mœurs, etc. des Français, depuis la mort de Louis XIII jusqu'à nos jours; contenant le tableau de la Cour, de la société et de la littérature du XVIII siècle ou l'Esprit des étiquettes et des usages anciens comparés aux modernes, 2 vols., Paris, P. Mongié, 1818. 
30. See among others, Fabrice Preyat, "Apologétique féminine", in Dictionnaire des femmes des Lumières, V. André, H. Krief eds., Paris, Champion, 2015.

31. This insertion between page 241 and 400 creates a mirroring effect between the memoir and the article which goes beyond the scope of this paper, but which we intend to explore elsewhere.

32. Dictionnaire critique et raisonné, op. cit., p. 249-250.

33. Théâtre à l'usage des jeunes personnes, tome 1, Paris, Lambert, 1780 .

34. Mémoires, 1825, tome I, p. 12-13.

35. La Colombe, Scene 3, eome II in both editions of Théâtre à l'usage des jeunes personnes.

36. Tome I, p. 246-250.

37. Paris, impr. de Knapen, 1774.

38. Tome I, p. 250-251.

39. Regarding the Feast of the Rosière, see my article in Dictionnaire des femmes des Lumières, op. cit., tome 1, p. 479-483.

40. Théâtre à l'usage des jeunes personnes, Paris, Lambert, 1785, tome III.

41. Both published in Paris by Maradan. I shall focus on the first.

42. Les souvenirs de Félicie $L^{* * *}$, Paris, Maradan, 1804, p. 3.

43. Ibid., p. 6.

44. Ibid., p. 8.

45. Ibid., p. 264-281.

46. Ibid., p. 7.

47. Ibid., p. 10.

48. Ibid., p. 197-216.

49. Mémoires, tome II, p. 320 sq.

50. Les Souvenirs, p. 290 sq.

51. Mémoires, tome II, p. 1 sq.

52. Les Souvenirs, p. 216 sq.

53. Mémoires, tome IX, p. $152 \mathrm{sq}$.

54. Paris, Maradan, 1805, p. 138 sq.

55. Les Souvenirs de Félicie L***, p. 53.

56. The complete title is Arabesques mythologiques ou Les Attributs de toutes les divinités de la fable en 54 planches gravées d'après les dessins coloriés de Mme de Genlis. Le texte contenant l'histoire des faux dieux, de leur culte, le détail des cérémonies religieuses, etc. précédé d'un discours sur la mythologie en général et particulièrement sur l'influence que dut avoir le paganisme sur le caractère, les mours et la littérature des anciens Grecs et des Romains, 2 vols., Paris, Charles Barrois, 1810.

57. Le Dernier voyage de Nelgis ou Mémoires d'un vieillard, 2 vol., Paris, Roux, 1828.

58. This work, like Les souvenirs de Félicie $L^{* * *}$, is made up of a series of texts integrated in a variety of ways, including short stories such as: Une Femme seule (already published in Le Petit portefeuille des dames, 1826, tome I, Paris : [editor missing], p. 10 sq., and Tout sentiment, p. 106 sq.; but also tales told by a protagonist like the story of Carillon the dog, p. $35 s q$ as told by the Marquis d'Aligre; or that of Séraphie as told by Bléval, p. 59 sq.; the story of the d'Aligre family read by Bléval p. 89 sq.).

59. Ibid., tome I, p. 30.

60. See the Mémoires quoted above, Ibid., tome I, p. 30, note 2. There is also this formula: "See the author's memoirs where this matter is recounted in detail", Ibid., p. 27.

61. Ibid., p. 4.

62. Ibid., p. 73, note 1 .

63. Mémoires, tome I, p. $36 \mathrm{sq}$.

64. Le Dernier voyage de Nelgis, p. 153 sq. 


\section{ABSTRACTS}

Female memoirs play off the complex status of personal testimony. The multifarious works of Mme de Genlis are a fascinating example of the tensions running between didactic texts, memoirs, remembrances, portraits and anecdotes that are there hidden under the surface of these hybrid texts. Above all, they make up a monumental work toward which converge a number of early texts and fragments of various types.

Les mémoires féminins s'appuient sur un statut complexe du témoignage. L'œuvre polygraphe de Mme de Genlis constitue un exemple passionnant de ces tensions entre textes didactiques, textes mémoriels, souvenirs, portrait et anecdotes qu'esquissent à la dérobée des textes hybrides. Et surtout, ils constituent un massif vers lequel convergent nombre de textes ou de parties de textes antérieurs, de nature très variée.

\section{INDEX}

Keywords: autobiographies, Genlis (Mme de), memoirs, witness, women writers

Mots-clés: autobiographies, Genlis (Mme de), mémoires, femme écrivain, témoignage

\section{AUTHORS}

MARIE-EMMANUELLE PLAGNOL 